\title{
An English-Igbo Translation of Palm Oil Production and Processing Terms for Human Development
}

\author{
Daniel Ihunanya Ilechukwu \\ http://dx.doi./org/10.4314/ujah.v18i2.8
}

\section{Abstract}

The Igbo speaking people are well known for Palm Oil production and processing in Nigeria. This occupation is one of the lucrative ventures among other trades or occupations for which the Igbo man expresses himself. With the recent technological advancement in the method of production and processing of palm oil, more English terms that do not exist in the Igbo language create communication problems. It is expected that Igbo farmers of South Eastern Nigeria be equipped with the Igbo equivalents of both the new and old terms involved in this venture for a balanced and free flow of communication. To achieve this objective, the technical terms involved in palm oil production and unit operations are documented (translated) from the English to Igbo language with the aid of different translation techniques. Method employed is a survey research. Data was also collected from five states of the South Eastern Nigeria, namely: Abia, Anambra, Enugu, Imo, and Ebonyi states respectively. Findings of the study indicate that some English terms have no Igbo equivalents, which calls for the documentation of terms in this area. Again, some mediocre translators create terms indiscriminately without following the morphological rules involved in the process thereby making it difficult to comprehend. Moreso; some terms do not have its equivalents in the target language (Igbo). Based on these findings, it is recommended that the federal government of Nigeria should give the needed support for research development; the mass media 
should help in making newly created terms popular; translators involved in terminology should register with international organizations for unification of terminological neologism, etc. This research will be of great importance to farmers of palm oil production and processing, teachers and students in the area of study, the mass media and the general public for free flow of communication. The study was concluded based on the findings with summary, conclusion and suggestion for further studies.

\section{Introduction}

Oil palm botanically called "Elaeis Guineensis," appears to be one of the cash crops that Nigeria cares for. It serves as a source of revenue to a greater number of rural population of the South Eastern Nigeria and source of revenue to Nigeria as a whole. In Nigeria, palm oil is produced in the following states: Imo, Cross River, Akwa Ibom, Rivers, Anambra, Abia, Oyo, Ondo and Edo. Others are: Osun, Delta, Ogun, Benue and Kogi states. In Anambra state, oil palm is produced in large quantities in Igbariam, Awka and Ozubulu respectively. Also oil palm is grown and produced in a large quantity at Akpofu in Nkanu West L.G.A. in Enugu state.

Palm oil fruit contains two kinds of oil - the palm kernel oil and the palm oil that gives vitamin A. The palm kernel is a source of two economic products - palm kernel oil and palm kernel cake. Palm kernel oil can be used for cooking and frying, production of fats and margarine for plastics, animal feed and soap production. When the zone is $10^{\circ}$ North and $10^{\circ}$ South of the equator, oil palm produces best. According to Hardter et al (1997:18), "The rainfall requirement of oil palm falls between $2500-3500 \mathrm{~mm}$ per year. 
Oil palm has a life span of about 25 years thus: $0-3$ years for the young immature, 4-8 years for the young mature and over 8 years for the matured phase. The introduction of the modern techniques in the production of palm oil production and processing in the Igbo speaking areas of South Eastern Nigeria has infused language barriers among farmers in this domain. Many indigenous farmers do not have any idea of what to call some of the foreign terms involved in the business they are into. Transaction is almost impossible for they are expected to acquire the modern techniques in the area of palm oil production and processing.

Gradually, most of the elderly palm oil production farmers are dying off and the younger ones are not eager to take after them in this business. The fear now is that when they are no more, the language register in this domain will extinct. In order to prevent this omen, the researcher has taken the pains to translate from English language to Igbo language, documented materials on palm oil production and processing with a view to coming out with the correct and exact equivalent terms that will benefit the Igbo indigenous farmers in discussing this field.

\section{The Concept of Translation}

The word translation is derived from the Latin word "translatio" meaning "to carry across," House (2009:4) defines translation as "the process of replacing a text in one language by a text in another language." This means in essence, the restatement of the forms of one language in another: The Chief means of exchanging information between different language communities. There is the need to emphasize that speaking two or more languages does not qualify one as a translator; rather translation is an acquired skill of expressing a particular culture so that the message conveyed to the 
new audience remains unchanged. This skills is acquired over many years of practice after the individual has acquired the necessary basic language skills.

\section{Fidelity and Fluency}

Fidelity (or "faithfulness") and fluency are two qualities that have been regarded as ideals to be striven for in translation, particularly "literary translation." "Fidelity" pertains to the extent to which a translation accurately renders the meaning of the source text, without adding to or subtracting from it, without emphasizing or de-emphasizing any part of the meaning, and otherwise without distorting it. "Fluency" pertains to the extent to which a translation appears to a native speaker of the target language to have originally been written in that language, and conforms to the language's grammatical, syntactic and idiomatic conventions.

A competent translator must have the following qualities:

i. Must be familiar with the subject matter of the text being translated

ii. A good knowledge of the language, written and spoken, from which he is translating.

iii. Must have an excellent command of the language into which he is translating (the source)

iv. A profound understanding of the etymological and idiomatic correlates between the two languages.

v. A finely tuned sense of when to "metaphrase" ("translate literally") and when to "paraphrase" so as to assure true rather than spurious "equivalents" between the source and target language texts. 


\section{Translation Techniques}

Ezeuko (1997) enumerates the seven special skills employed for the purpose of good translation as proposed by J.P. Vinary and J. Darbelnett, thus:

i. Loaning: This is seen as borrowing or lifting words from one language into another without the word being translated or modified. Loaning could involve expression and not words alone. One outstanding rule with Igbo is that the orthography and phonology of the language must be used in writing the word borrowed Ezeuko (1997).

\section{Examples:}

\begin{tabular}{l|l} 
English & Igbo \\
\hline Ball & Bọọl \\
Engine & Njin \\
Linguistic & Linguistik \\
Astrology & Astrọloji \\
Office & Ọfis
\end{tabular}

ii. Calque: This is the process of copying or imitating the structure of a foreign language term in coining an equivalent indigenous term.

\section{Examples:}

\begin{tabular}{l|l} 
English & Igbo \\
\hline Happy Christmas & Hapi Krismasị \\
Science-fiction & Sayens fikshọm
\end{tabular}


iii. Adaptation: This is the process of copying or borrowing a word in the indigenous orthography although the sound may not correspond. Adaptation is close to naturalization.

\section{Examples:}

\begin{tabular}{l|l} 
English & Igbo \\
\hline Linguistic & Lingwistiiki \\
Certificate & Safrikeeti \\
Ball & Bọọlụ \\
Degree & Digirii \\
Oxygen & Osijin \\
Fridge & Firiiji
\end{tabular}

iv. Naturalization: This is the act of borrowing words and using the orthography of the target language (TL) in writing them according to the sound of the language. It is otherwise known as Igbonization.

\section{Examples:}

\begin{tabular}{l|l} 
English & Igbo \\
\hline Agriculture & Agrịkọlchọ \\
Astrology & Astrọlọji \\
Astronomy & Astronomy \\
Geology & Jiọlọji \\
Morphology & Mọfọlọji
\end{tabular}

v. Transposition: This involves two or more items changing position. It is a change in grammatical category. 


\section{Examples:}

\section{English}

He insisted on immediate payment

Men are insane

Igbo

Ó sìrì ónwú kà á kwúó yā úgwọ ńgwángwā ísí ádīghī úmùnwókẹ mma

Modulation: This is the act of changing the view point of the message. It can either be obligatory or optional. For instance, in Igbo, euphemism may be used instead of writing the actual words/expressions.

\section{Examples:}

\begin{tabular}{l|l} 
Igbo & Igbo \\
\hline Ó jèrè ínỳụ ńsí & O gàrà ihhụ nwáànyí múrú nwá n'óhịá \\
Ó nà-áwìra ára & ísí ádīghì ya mma \\
Ó nà-èzú óhī & Ó nà-èmé áká ńtùtù
\end{tabular}

Equivalence: Equivalence is depicting a relationship of equal value. It implies to idiomatic expressions, proverbs, etc. Here, you do not have the same style, but you have something that can or is similar in arriving at the same meaning.

\begin{tabular}{l|l} 
English & \multicolumn{1}{|c}{ Igbo } \\
If there is no cross there will be no crown & $\begin{array}{l}\text { Áká ájá aja nà-èbúté } \\
\text { onú mmánú mmānụ } \\
\text { É méé ńgwángwà è } \\
\text { meghàrá ódachí } \\
\text { A stitch in time saves nine }\end{array}$ \\
$\begin{array}{l}\text { Wèré éhìhiè chòwá éwú } \\
\text { ójiī. }\end{array}$
\end{tabular}




\section{The Place of Terminology in Translation}

Ezeuko (1997) opines that most of African language in the written form (the Igbo language in particular) were developed when the Western form of education was introduced and this dates back at the epoch of the Trans Atlantic slave trade. By 1777 some words could be written in Igbo. Although there is no doubt that their spellings were irregular since the missionaries wrote them down as the words sounded to them. With the review of literature, words more technically termed lexems or lexical items, as Ronald (1981:14) puts it, are symbol in human languages that encode arbitrary but constant relationships between sign vehicles and signaled entities. They are life blood of language. In the above, words are the means by which meaning and forms are associated. But seeing words as a syntactic unit, symbolizes meaning attached as members of grammatical categories (nouns, verb, adjective and so on). What we are saying is that the clarity of concepts in relation to sign and referent will help more in making meaning concrete. Every language has the necessary linguistic resources to express the preoccupation of her speakers.

\section{Source Text (English Language)}

Palm Oil Production and Processing: Unit Operations terms

Harvesting Technique and Handling Effect

Retrieved from http://www.FAO.com - Kwasi (2002)

\section{S:L (English)}

In the early stages of fruit formation, the oil content of the fruit is very low. As the fruit approaches maturity, the formation of oil increases rapidly to about 50 percent of mesocarp weight. In a fresh ripe, un-bruised fruit, the free fatty acid (FFA) content of the oil is below 0.3 percent. However, in the ripe fruit, the exocarp 
becomes soft and is more easily attacked by lipolytic enzymes, especially at the base when the fruit becomes detached from the bunch. The enzymatic attack results in an increase in the FFA of the oil through hydrolysis. Research has shown that if the fruit is bruised, the FFA in the damaged part of the fruit increases rapidly to 60 percent in an hour. There is therefore great variation in the composition and quality within the bunch, depending on how much the bunch has been bruised.

Harvesting involves the cutting of the bunch from the tree and allowing it to fall to the ground by gravity. Fruits may be damaged in the process of prunning palm fronds to expose the bunch base to facilitate bunch cutting. As the bunch (weighing about $25 \mathrm{~kg}$ ) falls to the ground, the impact bruises the fruit. During loading and unloading of bunches into and out of transport containers, there are further opportunities for the fruit to be bruised.

In Africa, most bunches are conveyed to the processing site in baskets carried on the head. To dismount the load, the tendency is to dump contents of the basket unto the ground. This results in more bruises. Sometimes trucks and push carts, unable to set bunches down gently, convey the cargo from the village to the processing sites. Again, tumbling the fruit bunches from the carriers is rough, resulting in bruising of the soft exocarp. In any case, care should be exercised in handling the fruit to avoid excessive bruising.

One answer to the many way in which harvesting, transportation and handling of bunches can cause fruit to be damaged is to process the fruit as early as possible after harvest, say within 48 hours. However, the author believes it is better to leave the fruit to 
ferment for a few days before processing. Connoisseurs of good edible palm oil knows that the increased FFA only adds 'bite' to the oil has good laxative effects. The free fatty acid content is not a quality issue for those who consume the crude oil directly, although it is for oil refiners, who have a problem with neutralization of high FFA content palm oil.

\section{Bunch Reception}

Fresh fruit arrives from the field as bunches or loose fruit. The fresh fruit is normally emptied into wooden boxes suitable for weighing on a scale so that quantities of fruit arriving at the processing site may be checked. Large installations use weighbridges to weigh materials in trucks. The quality standard achieved is initially dependent on the quality of bunches arriving at the mill. The mill cannot improve upon this quality but can prevent or minimize further deterioration.

The field factors that affect the composition and final quality of palm oil are genetic, age of the tree, agronomic, environmental, harvesting technique, handling and transport. Many of these factors are beyond the control of a small-scale processor. Perhaps some control may be exercised over harvesting technique as well as postharvest transport and handling.

\section{Threshing (removal of fruit from the bunches)}

The fresh fruit bunch consists of fruit embedded in spikelets growing on a main stem. Manual threshing is achieved by cutting the fruit-lade spikelets from the bunch stem with an axe or matchet and then separating the fruit from the spikelets by hand. Children and the elderly in the village earn income as casual labourers performing this activity at the factory site. 
In a mechanized system a rotating drum or fixed drum equipped with rotary beater bars detach the fruit from the bunch, leaving the spikelets on the stem. Most small scale processor do not have the capacity to generate steam for sterilization. Therefore, the threshed fruits are cooked in water. Whole bunches which include spikelets absorb a lot of water in the cooking process. High-pressure steam is more effective in heating bunches without losing much water. Therefore most small-scale operations thresh bunches before the fruits are cooked, while high-pressure sterilization systems thresh bunches after heating to loosen the fruits.

\section{Sterilization of Bunches}

Sterilization or cooking means the use of high-temperature wetheat treatment of loose fruits. Cooking normally uses hot water; sterilization uses pressurized steam. The cooking action serves several purposes. For large-scale installations, where bunches are cooked whole, the wet heat weakens the fruit stem and make it easy to remove the fruit from bunches on shaking or tumbling in the threshing machine.

Fruit cooking weakens the pulp structure, softening it and making it easier to detach the fibrous material and its contents during the digestion process. The high heat is enough to partially disrupt the oil-containing cells in the mesocarp and permits oil to be released more readily.

However, during sterilization, it is important to ensure evaluation of air from the sterilizer. Air not only acts as a barrier to heat transfer, but oil oxidation increases considerably at high temperatures, hence oxidation risks are high during sterilization. 
Over-sterilization can also lead to poor bleach ability of the resultant oil. Sterilization is also the chief factor responsible for the discolouration of palm kernels, leading to poor bleach ability of the extracted oil and reduction of the protein value of the press cake.

\section{Target Text (Igbo Language)}

Usoro Niile Ndị Ụlộ̣ụ Mmanụ Si Apịchapụta Mmanụ

Usoro E Si Egbutu Akwụ Wee Megide Nweta Mmanụ

(E nwetara ya na http://www.FAO.com)

\section{(TL: Igbo)}

$\mathrm{Na}$ mmalite akwụ ji afọnye mkpụrụ, mmanụ na-adị na mpkụrụakwụ na-epe mpe. Mgbe mkpụrụakwụ ahụ na-achọ ịcha, mmanụ ga-adịzị na mkpụrụakwụ ahụ ga-agbalite ruo ihe dị ka ndịnarị iri ise arụ akwụ dara. A bịa n’akwụ ka chara ọhụrụ, nke akwụ ya akpụchaghị akpụcha, agbidi ụka nkịtị (FFA) mmanụ dị na ya agaghi eru ndịnarị dị 0.3. Etuosiladị, a bia na mkpụrụakwụ chara acha, ahụ ya na-adị nro nke na nrichaakwụ ga-enwe ike imekpa ya ahụ, tụmadụ n'ọnụ akwụ mgbe a ghụpụtacharala mkpụrụakwụ n’ogbe ya. Mmekpaahụ nke nrichaakwụ na-eme ka agbidi ụka (FFA) bawanye na mmanụ site na mmiri ka dị n'akwụ. Nchọpụta emeela ka a mara na ọ bụrụ na mkpụrụakwụ akpụchaa, na agbidi ụka ga-adị n'ebe kpụchara akpụcha ga-abawanye ihe ruru pasent iri isii n'otu awa. N'ihi ya, a na-enwe nnukwu ihe dị iche n'omume mkpụrụakwụ n'ogbeakwu n'inweta nke omume ya bụ kpoo, site n’ụdị mkpụcha ogbeakwụ ahụ kpụchara.

Igbu akwụ gụnyere igbutu ogbe akwu site na nkwụ ma hapụ ya ka ọ daa n'ala n'ike. Ọtụtụ mkpụrụakwụ nwere ike ịla n’iyi/bibie mgbe a na-egbuchasị igu ka ohere wee dị ebe a ga-esi gbutuo isi akwụ. Ka ogbeakwụ (àrú ya ga-adị ihe dị ka kg iri abụọ na ise) na- 
adaru n'ala, ike ahụ o ji daa, na-enye mkpụrụakwụ apa. Mgbe a ga na-adọnye ma na-ebutu ya n'ihe e ji ebu ya, ogbeakwụ ndị a gaesikwa n’ụzọ dị etu a nwee apa.

N'Afrịka, a na-eji nkata, were isi ebuga ọtụtụ ogbeakwụ ndị a ebe a ga-arụchapụta ha. N'ibutu ogbeakwụ a n'isi, ọ na-abụkari isi n' ísí wụghapụ ya n'ala site na nkata. Nke a na-eme ka o nwekwuo apa. Mgbe ụfọdụ ụgbọala ibu na trọọk ọkwụkwa anaghị enwe ike ibutu ogbeakwụ, na nwayọo, a na-esite n'ime obodo busaa akwụ n'ebe dị iche iche a na-apịchapụta mmanụ. Ọzọ, isi n'ihe e ji buru ogbeakwụ kpuo ya ihu n'ala jọrọ njọ, n'ihina ọ na-eme ka ahụ akwụ dị nro nwee apa. Etu ọdịla, a ga-akpachapụ anya etu esi ebu akwụ iji gbochie oke mgbụhịa.

Otu ụzọ isi gbochi apa mkpụrụakwụ na-enwe n’oge a na-egbutu ya, oge obubu ya na oge a na-ebutu ya bụ site n'ịrụchapụta ya n'ezigbo oge mgbe e gbutuchara ya n'ihe dị ka agbata awa iri anọ na asatọ. Etuosiladị, odee kwenyere na o ka mma ka a hapụ akwụ e gbuturu ka ọ nọo abalị olenaole ka o wee nwoo tupu a sụ̣ ya. Onye ma anya ezigbo mmanụ nri maara na agbidi ụka ibu ibu n'akwụ bụ obere ihe ka ọ ga-agbakwụnye n'ụtọ mmaụ. O nwegodighị ka e mere, mmanụ nwere agbidi ụka n'ebe o buru ibu na-enye aka ikpocha afọ. Mmanụ enweghị agbidi ụka abụghị nke a na-ahụta dịka ịbụ kpoo n’ebe ndị na-eri ya ozigbo nọ, kama ọ bụ maka ndị ji ya arụpụta ihe, bụ ndị na-enwe nsogbu n'ịgbaeze agbidi ụka mgbe ọ dị na mmanụ.

\section{Íbūrưó Ógbè Akwụ É Bùlàtàrà}

A na-esi n'ubi ebulata akwụ ọhụrụ n’ụdị ogbe maọbụ n’ụdị mkpụrụakwụ nworo enwo. A na-awụnyekarị mkpụrụakwụ ọhụrụ a n'ime igbe osisi nke ga-adị mma iji chọpụta ole ọ ha n'ihe e ji 
achọpụta ole ihe han' árú, ka e wee nwee ike mata ole akwụ e butere n'ụlọọu a na-apaputa mmanụ ha. Nnukwu ụlọorụ na-eji igwe e ji ele ole ibu dị n'ụgbọala were achọpụta ole akwụ dị na nnukwu ụgbọala ibu ha. Inweta kpoo dị na mmanụ na-adabere n'etu e si kpachapụrụ ogbeakwụ batara n'ụlọọrụ anya. Ụlọorụ agaghị emenwu ka ogo ọnọdụ a rụlite kama ọ ga-egbochi mmanụ ịdị njọ.

Ihe dị icheiche gbasara odọ nkwụ na-emetụta etu mmanụ ga-adị gụnyere ụdịdị akwụ o bụ n'ekerechi ya, afọ ole ukwu nkwụ nọọrọla, etu e si rụọ ugbo ya, ala ebe ọ dị, etu e si gbutu ogbeakwụ, obubu ya na mbula ya. Ihe ndịa niile karịi onye ji aka apapụta mmanụ n'ebe o pere ope. O nwere ike, naani ebe o ga-emenwu ihe na ya bụ gbasara igbutu akwụ, obubu ya na mbula ya.

\section{Onwunwo Mkụrụ Akwụ (ịhọpụta mkpụrụakwụ dị n'ogbeakwụ)}

Ihe mebere ogbeakwụ gụnyere mkpụrụakwụ sọkwụnyere n'ụzarị aghangụ toro na nkwụ. A na-eji aka enwonwu akwụ site n'igbuchasị aghangụ bu mkpụrụakwụ site n'iji anyụike maọbụ mmāògè, ma were aka họpụta akwụ n'aghangụ. Ụmụaka na ndịokenye na-enweta ego n'ime obodo dịka ndị ọrụngo na-arụ ợụ ndị a n’ ụloọrụ mpapụta mmanụ

Site n'iji igwe rụọ ọrụ a, a na-eji drọọnụ mgbaokirikiri maọbụ nke nnọotuebe nke a rụnyere igwe ga na-kụchapụta mkpụrụakwụ n'ogbeakwụ n'akụchapụghị aghangụ n'isi/n'ogbeakwụ. Ọtụtụ ndị na-arụ ơrụ a n'obere anaghị enwenwu ike isipụta mmiri ọkụ ga-esi akwụ. N'ihi ya, a na-eji mmiri esi mkpụrụakwụ e nwopụtara n'ọkụ. Nnukwu ụzụ ọkụ na-aka enye aka n'isi ogbeakwụ n'alaghị ọtụtụ mmiri n'iyi. N'ihi ya ọtụtụ n'ime ndị na-apa mmanụ n'obere 
na-ebu ụzọ nwoo ogbeakwụ tupu ha esie mkpụrụakwụ. Ebe usoro iji nnukwu ụzụ ọkụ sie akwụ na-enwo ogbeakwụ mgbe nhọpụta.

Ọtụtụ obere ụlọọrụ mpapụta mmanụ na-eji aghangụ ndị mkpụrụakwụ adịghizị were eme nkụ e ji esi akwụ. Na nnukwu ụlọọrụ mpapụta mmanụ, a na-akpọ ogbeakwụ e nwoorola enwo ọụ. Ntụ ya nwere nri e ji azụ ala (Potasium) nke a na-ewechigha wụọ n’ubi dịka nriakụkụ.

\section{Òsísí Ógbè Akwụ}

Nsigbu maọbụ osisi pụtara iji mmiri na ọkụ chasiri ike wee sie mkpụrụ akwụ e nwoorola enwo. Osisi na-anabatakari mmiri ebe nsigbu na-anabatakarị ụzụ ọkụ. Ihe gbarasa osisi na-egbo ọtụtụ mkpa. Maka ebe e ji ọtụtụ nnukwu igwe apa mmanụ, ebe a na-esi akwụ n’ogbe mmiri ụzụ ọkụ na-ede ike mkpụrụakwụ ma mee ka ọ dị mfe inwopụta n'ogbe n’ataghị ahụhụ site n'ịyọgharị ya maọbụ iji igwe onwunwo akwụ wee nwoo ya. Osisi mkpụrụakwụ na-ede ime ya, mee ya ka ọ dị nro ka o wee dị mfe ịhọ avụrịvụ na ihe dị n’ime ya n'oge myọcha. Nnukwu ekpomọu ezuola ịkpaghara igbepenkandụ dị n’ime mkpụrụakwụ ohere mmanụ ịnaagbapụtawaga.

Etuosiladị, n’oge osisi maka nsigbu mmanụ, ọ dị mkpa na a gaagba mbọ hụ na ikuku pụsịị n’igwe nsigbu mmanụ. Ikuku abụghị naanị na ọ na-eme ka mmanụ dị ọụ jụọ oyi, kama ọ na-emekwa ka ume mmanụ rilie nnukwu elu ozigbo n'oge ọbụla e nwere ekpomọu; nke a kpatara na oghọm na-adị mgbe a na-esicha mmanu maka nje na-ebukari ibu.Isife mmanu oke nwere ike ime ka mmanụ chabọo. Osisi akwụ bụ ihe kacha akpata ọcha akị ji achagha, nke ga-eme ka mmanụ ghara inwe ezigbo ụcha, ya na ibelata ihe na-edozi ahụ kwesịị ịdị n'akị. 


\section{Summary}

The primary aim of this research has been translation of palm oil production and processing terms from English to Igbo. This study started with background information of the study as well as what it intends to examine. It also revealed the scope of the study, statement of the problem, purpose of research, significance of the study and design of the study. In addition, relevant theoretical and empirical studies related to the research were reviewed to give the study a theoretical background. The research population consisted of mainly the staff members of some palm oil processing units in Anambra, Abia, Imo, Enugu and Delta all in the South Eastern Nigeria. Data were collected from related texts and through oral interview by simple random sampling. In data analysis, the techniques employed in translating were exposed. The research findings enumerated below were the outcome of the investigation.

The major findings of this research work are summarized as follows:

a. There are not enough and proper avenues to disseminate newly created terms.

b. New terms are created by mediocre translators indeterminately without them abiding by the approaches to terms creation.

c. Some English terms have no Igbo equivalents, like "percent," this makes them appear sentential after translation.

d. There is still a big gap between terminology researchers and the policy making bodies of the language.

e. Most translated terms and findings in Igbo terminology by experts and teachers are not easily accepted.

f. Some terms were coined, adapted and borrowed to avoid creating vacuums. 
Daniel Ihunanya Ilechukwu

Nnamdi Azikiwe University

Awka

di.ilechukwu@unizik.edu.ng

\section{References}

Anyaehie, E.O. (1997). Studies in Terminology (Ed.) Okigwe: Fasmen Communications.

Catfford, J.C. (1974). Linguistic Theory of Translation. London: Oxford University Press.

Collerino, S. (1992). Considerations of General Theory of Terminology in the Interpreters Newsletter No. 4.

Ezeuko, R. (1997). Steps to Process for High Quality Rice Grains. M.A. Thesis, Abia State University, Uturu.

Ezinwoke, S.O. (2004). Tropical Field Crops. Owerri: Evans Books.

Genty, P.R. (1978). Oil Palm Pests in Latin America. London: Champman and Hall.

Hardter, R., Woo, Y.C. \& Obi, S.H. (1997). Intensive Plantation Cropping. London: Longman.

Hartley, C.W.S. (1988). The Oil Palm tropical Agricultural Series.

London: Longman.

House, J. (2009). Translation. New York: Oxford University press. Juan, P.V. (2005). Translation Theory. New York: Cornel University Press.

Kwasi, p. (2002). Small Scale Palm Oil Processing in Africa. Retrieved from http://www.FAO.Com on $30^{\text {th }}$ August.

Labov, W. (1972). Language in the Inner City: Studies in the Black English Vernacular. Philadelphia: University of Pennsylvania Press. 
Lecercle, J.J. (1990). The Violence of Language. London \& New York: Rontledge.

Levenston, E. (1996). Towards a Comparative Stylistics. Journal or American English Teachers. xv, 2: 94-98.

Malone, J. (1988). The Science of Linguistics in Art of Translation. Albany: State University of New York Press.

Mannion, A.M. (1998). Agricultural and Environmental Charges. England: John Wiley and Sons.

Nkwenti-Azeh, B. (1991). Translation Performance, Translation Process and Translation Strategies. Tubingen: Narr.

Okeke, J. (1995). Translation of English - Igbo and Language Engineering in the Electronic Media. Benin: Barloz Publishers Inc.

Okolo, D.A. (2004). National Tree Crop Development Unit. Owerri; Evans Printing.

Ray, A. (1997). La Terminology non et notion. France: Paris Press, University de France.

Ronald, C. (1981). The Biology and Evolution of Language. Masschusetts: Harvard University Press.

Rotistv, M. (1985). Terminology and Language. London: Oxford University Press.

Sager, J.c. (1994). Language Engineering and Translation: Consequences of Automation. Amsterdam: Benjamins.

Turner, I. \& Emden, A. (1960). Oil Palm Pests in Latin America. London: Chapman and Hall.

Yannani, L. (1987). Answer to Questions on Discussion on International Experience. London: Edward Arnold. 